\title{
Inventary of the Sponge Fauna of the cemitério Paleolake, Catalão, Goiás, Brazil
}

\author{
VANESSA DE SOUZA MACHADO ${ }^{1}$, CECILIA VOLKMER-RIBEIRO ${ }^{2}$ AND ROBERTO IANNUZZI $^{3}$ \\ ${ }^{1}$ Programa de Pós-Graduação em Geociências, Instituto de Geociências, Universidade Federal do Rio Grande do Sul (UFRGS), \\ Av. Bento Gonçalves, 9500, Prédio 43113, 91501-970 Porto Alegre, RS, Brasil \\ ${ }^{2}$ Seção de Invertebrados Inferiores, Setor de Poríferos Continentais, Museu de Ciências Naturais (MCN), \\ Fundação Zoobotânica do Rio Grande do Sul (FZB), Av. Salvador França, 1427, 90690-000 Porto Alegre, RS, Brasil. \\ ${ }^{3}$ Instituto de Geociências, Departamento de Paleontologia e Estratigrafia, UFRGS, \\ Av. Bento Gonçalves, 9500, Prédio 43113, 91501-970 Porto Alegre, RS, Brasil.
}

Manuscript received on June 15, 2010; accepted for publication on October 26, 2010

\begin{abstract}
The Cemitério Paleolake, Catalão, Goiás, is a lacustrine deposit that is rich in spicules of continental sponges. These spicules, which are present in three sections (1-3), were analyzed for the taxonomic identification of the species in order to reconstruct the late Quaternary palaeoenvironment. An indigenous assemblage of lentic sponges was found, consisting of Metania spinata (Carter 1881), Dosilia pydanieli Volkmer-Ribeiro (1992), Radiospongilla amazonensis Volkmer-Ribeiro and Maciel (1983), Trochospongilla variabilis Bonetto and Ezcurra de Drago (1973), Corvomeyenia thumi (Traxler 1895), Heterorotula fistula VolkmerRibeiro and Motta (1995), plus Corvoheteromeyenia australis (Bonetto and Ezcurra de Drago 1966), which here has its first record in an assemblage formed by biosiliceous deposits. Furthermore, at the base of the sections, spicules of sponges from lotic environments were detected, including Corvospongilla seckti Bonetto and Ezcurra de Drago (1966), Oncosclera navicella (Carter 1881) and Eunapius fragilis (Leidy 1851), which suggests a contribution from flowing water. We identified 25 spongofacies horizons caused by sponge assemblages typical of a lentic environment, dated from at least 39,700 years BP., and currently occurring in lakes typical of the Cerrado Biome.
\end{abstract}

Key words: Cerrado Biome, continental sponges, Quaternary paleointerpretations, sediments, spicules.

\section{INTRODUCTION}

Continental sponges (Phylum Porifera) are animals that can be found in any, permanent or temporary, body of fresh water under natural conditions, e.g., rivers, lakes and in coastal mixohaline environments. They are sessile and live attached to a submerged or an emergent substrate, such as macrophyte

Correspondence to: Vanessa de Souza Machado

E-mail: biologavsm@gmail.com roots, rocks, branches of riparian vegetation or tree trunks in regions that experience seasonal flooding, such as the floodplains of the major Amazonian rivers (Volkmer-Ribeiro and Pauls 2000). The specific identification of continental sponges is based on the set of spicules of each species. The gemmoscleres, which are the spicules of the gemmules, are the most important morphological character in the characterization of families, genera and species. Likewise important are microscleres 
and megascleres, which are the spicules that make up the body of the animal. The gemmules, which are the asexual reproduction structures, have been crucial in the occupation of continental environments and ensure the survival of the species in seasonal habitats, being also important structures for the dispersion of the animals within aquatic microenvironments (Volkmer-Ribeiro 1981).

The siliceous spicules of continental sponges can be seen in sedimentary rocks due to their amorphous silica composition (opal). Following death, the body of the sponge remains in the water column, and the spongin rapidly decomposes, releasing the siliceous spicules that are deposited in sediments. When the drainage is reduced and the production of the sponge is voluminous, the accumulation of these spicules in sediments can produce biosiliceous mineral deposits known as spongillites (Volkmer-Ribeiro 1992, VolkmerRibeiro and Motta 1995).

The taxonomic and ecological study of this fauna has revealed the preference of different species/assemblages for specific environments (Volkmer-Ribeiro and Machado 2007). As these events are repeated, it has been proposed that these species/assemblages be used as indicators of such environments, thus providing tools for paleoenvironmental interpretations in the Quaternary.

The first studies involving the use of spicules from continental sponges in environmental paleointerpretation were carried out as from 1974, and demonstrated the occurrence of spicules of extant species in sedimentary rocks of the Quaternary (Racek 1974, Hall and Herrmann 1980, Harrison et al. 1979, Harrison and Warner 1986, Harrison 1988, Gaiser et al. 2004).

Martin et al. (1992) identified the continental sponge Corvomeyenia thumi (Traxler 1895) in a paleolake profile from Eastern Amazonia in the Serra dos Carajás, Pará, Brazil, dated between 7,000 to 4,000 years BP. This species is adapted to episodic drought, which led to the conclusion that the inferred regression of the forest was not due to ongoing drought, but to successive periods of drought, a result corroborated by geochemical and palynological evidence. Sifeddine et al. (1994) expanded the study to another paleolake profile in Carajás (Southern Amazon) and showed that both lakes may have evolved through different paleohydrological periods. They also identified in the last 8000 years BP. the alternation of charcoal deposits, which indicate paleofires, and amorphous silica in the form of sponge spicules from C. thumi. The authors concluded that, during this time period, the weather conditions were probably on average better for the development of forests, but these developments were regularly interrupted by fire since the presence of $C$. thumi gemmoscleres indicated successive periods of drought, with a reduced water column.

Volkmer-Ribeiro and Turcq (1996) presented a scanning electron microscopy (SEM) analysis of spines from $C$. thumi present in two profiles from the Serra dos Carajás, and demonstrated that extremely short periods of immersion, related to the availability of precipitation and runoff in the system, can cause a gradual series of incipient formations preserved at the time of deposition of sediments. They also concluded that the sequence of spicules observed in both profiles indicated a global climate change, with stages of retraction and expansion of forests during the last 30,000 years, which is supported by pollen and geochemical analysis.

Volkmer-Ribeiro et al. (2004) statistically evaluated the content of gemmoscleres from the species Ephydatia facunda Weltner (1895) in current sediments from seven coastal lagoons in the Taim Hydrological System, Rio Grande do Sul, Brazil. The applied methodology revealed the evolution of this system, with the greatest sponge production related to an enrichment of organic matter, which reaches its culmination in the marsh environment. Volkmer-Ribeiro et al. (2007) again identified the species $E$. facunda in sediments of the 
Luján Formation, west of the city of Luján, $63 \mathrm{~km}$ from Buenos Aires, Argentina, concluding from the evidence that there had been a period of lacustrine sedimentation in a coastal lagoon environment (from 11,060 to 10,420 years BP.), which is also corroborated by the presence of frustules from the diatom Hyalodiscus subtilis (Bailey). They also pointed to a relationship between this deposit and transgressive events prior to the studied formation.

Parolin et al. (2007), through the presence of continental sponge spicules in sediment profiles in the floodplain of the Esperança River, Taquarussu region, Mato Grosso do Sul, Brazil, suggest the occurrence of flood pulse between 4610-4010 years BP. Almeida et al. (2009), after taxonomic and taphonomic analysis of the spicules of continental sponges in spongolite deposits in the region of João Pinheiro, northwest of Minas Gerais, Brazil, pointed to alternating periods of wet and cold weather and drier climate, with torrential rainfall between the Upper Pleistocene and Holocene in this region.

Parolin et al. (2008), after the identification of sponge spicules typical of distinct environments and using a vibro-core sample in sediments at Samambaia Lake, Taquarussu, Mato Grosso do Sul, Brazil, characterized the alternation of lentic and lotic phases from the late Pleistocene to middle Holocene. At that time, the term "spongofacies" was proposed and defined for facies with a predominance of sponge spicules that, when identified, indicate specific paleoenvironmental characteristics.

The Cemitério Paleolake deposit formed over a dome of carbonatite magma rock in the central part of the Catalão I Carbonatite Complex, in Catalão, Goiás. The rocks in the deposit have a large amount of continental sponge spicules, which to date had not been identified. The focus of this paper, regarding a taxonomic study of this paleolake deposit, reveals that sponge assemblages contributed substantially to this deposit. The spongofacies technique of Parolin et al. (2008) was applied in order to identify horizons and develop a more robust understanding on the evolution of the deposit during the Quaternary. The results presented herein correspond to an unpublished component of the Master's thesis of the senior author.

\section{MATERIALS AND METHODS}

The Ultramafic-alkaline-carbonatite complex of Catalão I is located $15 \mathrm{~km}$ from the center of the municipality of Catalão, southeast Goiás $\left(18^{\circ} 08^{\prime} \mathrm{S}\right.$ $47^{\circ} 08^{\prime} \mathrm{W}$; Fig. 1). The Cemitério paleolake outcrop includes a lacustrine deposit with a continuous exposure (Fig. 2) caused by the filling of a depression located in the central part of the Catalão I Carbonatite Complex, where the sedimentary rocks lie discordantly on a dome of magmatic carbonatite rock from the Upper Cretaceous (Ribeiro et al. 2001). Data were collected by Dr. Roberto Iannuzzi and Dr. Nelsa Cardoso by removing blocks of rock from each sediment layer, either manually or with the aid of machines provided by the Fosfértil mining company. Three stratigraphic columns were recorded in distinct localities along the exposure. Samples were collected from the three sites from top to bottom, with 21, 19 and 13 collected layers at Sites 1, 2 and 3, respectively (Figs. 2, 3).

For the Optical Microscope (OM) identification of the sponge spicules in the sediments, a specific laboratory technique was applied to obtain permanent slides. About $0.35 \mathrm{~cm}^{3}$ parcels of sediments were prepared following the procedure of Volkmer-Ribeiro (1985) for each of the sampled horizons at Sites 1,2 and 3. Three slides were prepared for each horizon subsample. In addition, specific dissociations were carried out for the release of spicules (Volkmer-Ribeiro and Turcq 1996) in order to produce clear Scanning Electron Microscope (SEM) images, which were obtained at the Microscopy Center of the Lutheran University of Brazil (ULBRA). 
The presence of spicules in different rocks was visually evaluated and qualified by OM (permanent slides) and in the rock fragments (Stereoscopic Microscope - magnifying glass) as: (S) spongofacies (abundant spicules, according to the definition proposed by Parolin et al. 2008); (F) few spicules; and (A) absence of spicules.
All sediments related to the layers and/or levels from the three Sections, as well as permanent slides and prepared SEM supports, have been cataloged in the Porifera collection of the Museum of Natural Science (MCN-POR), Zoobotanic Foundation of Rio Grande do Sul (FZB), with the reference MCNPOR nr 8147 to 8200 .

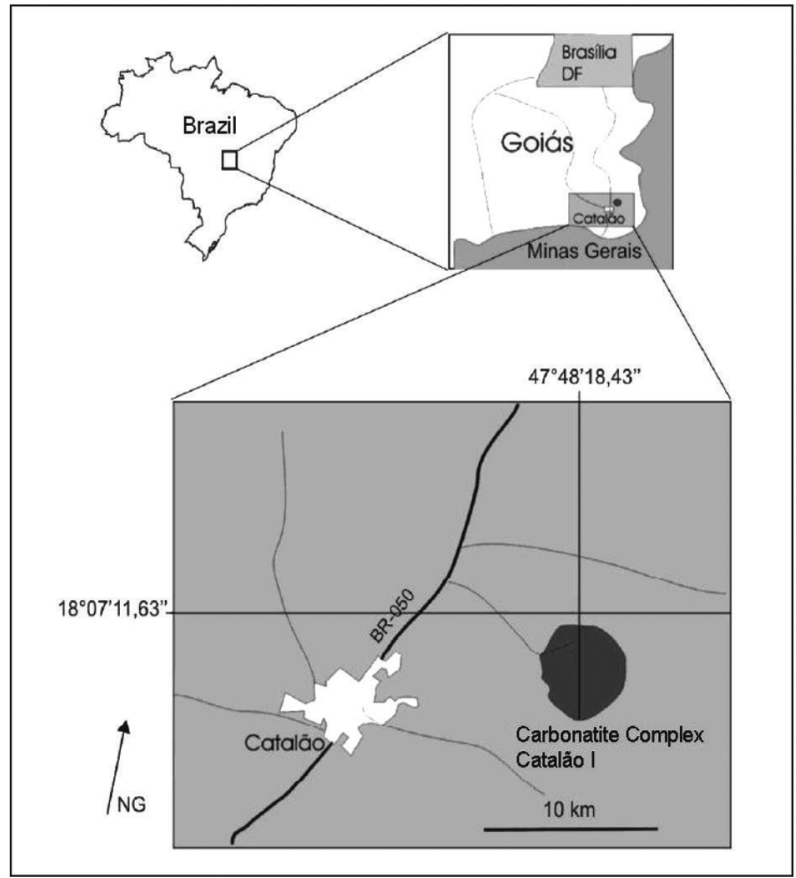

Fig. 1. Location map of the Carbonatitic Complex of Catalão I, which is the depositional site of the Cemitério Paleolake. Modified from Cardoso and Iannuzzi (2006).

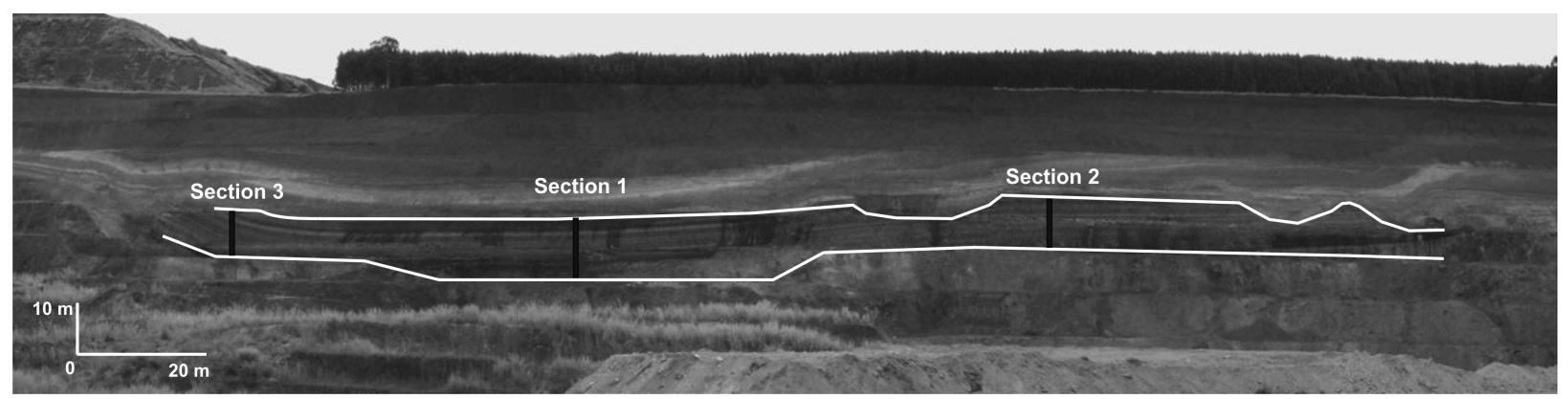

Fig. 2. Photograph of the Cemitério Paleolake. The white line traces the limits of the deposit. The black bars indicate the position of the three sampled sections. 


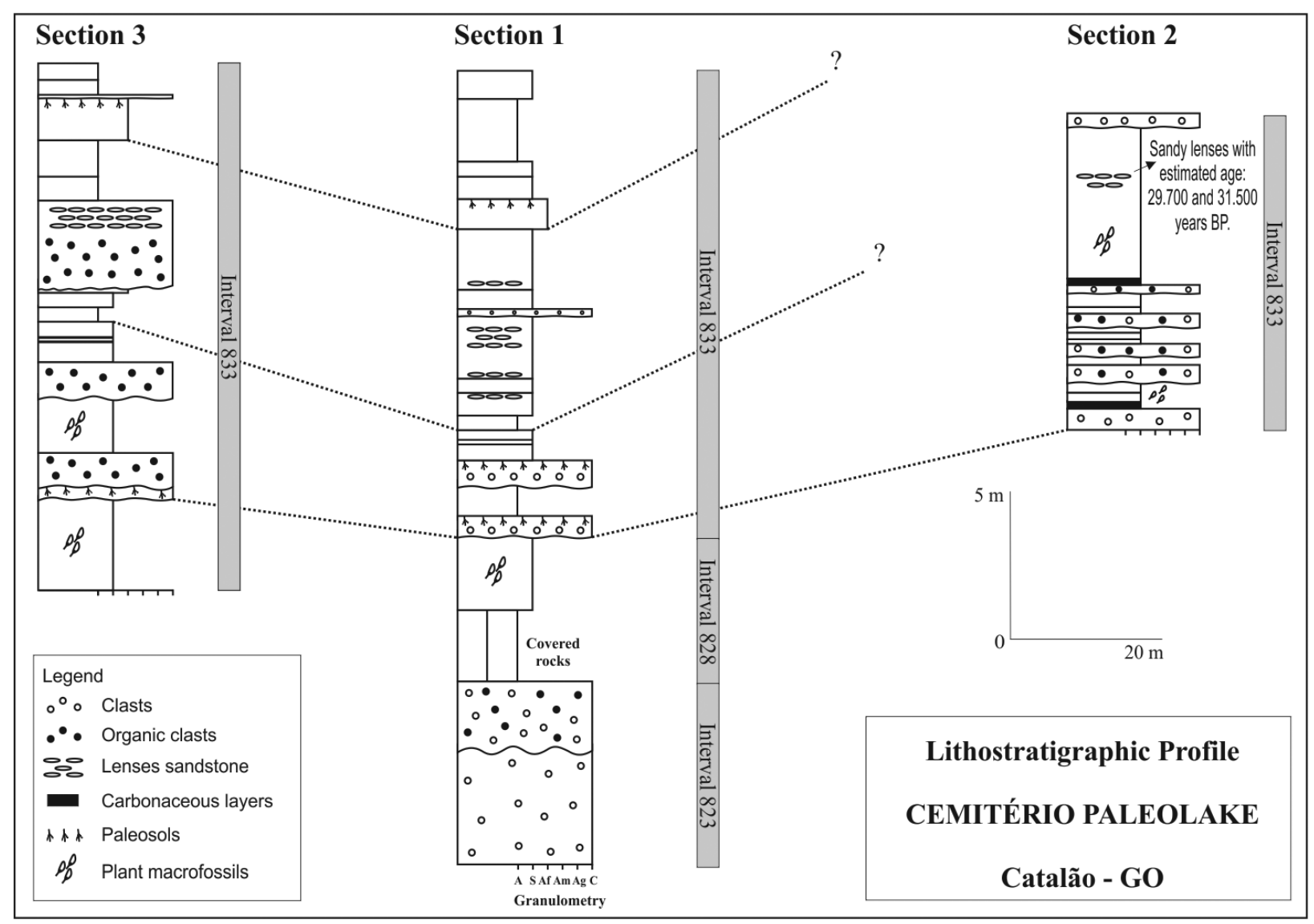

Fig. 3. Lithostratigraphic profile of the Cemitério Paleolake, Catalão, Goiás, showing the correlation among the three sections analyzed. From N.C., unpublished data. (A, argillite; S, siltstone; Af, fine sandstone; Am, medium sandstone; Ag, coarse sandstone; C, conglomerate).

\section{RESULTS}

TAXONOMIC STUDY

\section{Dosilia pydanieli \\ Volkmer-Ribeiro (1992)}

Fig. 4a; Table I

Dosilia pydanieli Volkmer-Ribeiro (1992): 329, Fig. 2e; Volkmer-Ribeiro and Motta (1995): 149; Volkmer-Ribeiro et al. (1998a): 274; (1998b): 411; Volkmer-Ribeiro (1999): 4; Cândido et al. (2000): 88, Figs. 3-11; Parolin et al. (2003): 17; (2008): 191, Figs. 6B, C, 7D, E; Almeida et al. (2009): 126, Figs. 2A, B; Cândido et al. (2010): 443-444, Figs. 56-62.

\section{TABLE I}

Category and measures $(\mu \mathrm{m})$ of spicules of $D$. pydanieli detected in the three studied sections. All categories are frequent.

\begin{tabular}{lcc}
\hline $\begin{array}{l}\text { Spicule } \\
\text { Categories }\end{array}$ & $\begin{array}{c}\text { Measures } \\
\text { Average } \\
\text { length }\end{array}$ & $\begin{array}{c}\text { Average } \\
\text { width }\end{array}$ \\
\hline $\begin{array}{l}\text { Gemmoscleres } \\
\text { Microscleres }\end{array}$ & 79 & 2.8 \\
$\begin{array}{l}\text { Fig. 4a } \\
\text { Megascleres }\end{array}$ & 38 & 1.9 \\
\hline
\end{tabular}


Radiospongilla amazonensis

Volkmer-Ribeiro and Maciel (1983)

Figs. 4b, c; Table II

Radiospongilla amazonensis Volkmer-Ribeiro and Maciel (1983): 255, Fig. 5; Volkmer-Ribeiro (1992): 323, Figs. 2D, 4B, C; Volkmer-Ribeiro and Motta (1995): 149; Volkmer-Ribeiro et al. (1998a): 274; (1998b): 411; Parolin et al. (2003): 17; Batista et al. (2003): 530; Tavares et al. (2003): 172, Fig. 8; Batista et al. (2007): 621, Fig. 34; Parolin et al. (2007): 21, Figs. 4B, B1; (2008): 191, Fig. 7H; Almeida et al. (2009): 126, Fig. 2G.

TABLE II

Category and measures $(\mu \mathrm{m})$ of spicules of $R$. amazonensis detected in the three studied sections. All categories are frequent.

Gemmoscleres are smaller than in the original description.

\begin{tabular}{lccc}
\hline Spicule & Measures & $\begin{array}{c}\text { Average } \\
\text { length }\end{array}$ & $\begin{array}{c}\text { Average } \\
\text { width }\end{array}$ \\
Categories & & & \\
\hline
\end{tabular}

\begin{tabular}{lcc} 
Megascleres & 240 & 14 \\
Fig. $4 \mathrm{~b}$ & & \\
$\begin{array}{l}\text { Gemmoscleres } \\
\text { Fig. } 4 \mathrm{c}\end{array}$ & 58 & 4.5 \\
& & \\
\hline
\end{tabular}

\section{Trochospongilla variabilis}

Bonetto and Ezcurra de Drago (1973)

Fig. 4d; Table III

Trochospongilla variabilis Bonetto and Ezcurra de Drago (1973): 15, Fig. 11; Volkmer-Ribeiro (1992): 323, Figs. 2C, 3; Volkmer-Ribeiro and Motta (1995): 149; Volkmer-Ribeiro et al. (1998b): 410; Volkmer-Ribeiro (1999): 4; Cândido et al. (2000): 79; Tavares et al. (2003): 176, Fig. 11; Batista et al. (2007): 620, Fig. 31; Volkmer-Ribeiro and Machado (2009): 338, Fig. 4; 340, Figs. 14-19; Almeida et al. (2009): 126, Fig. 2E.
TABLE III

Category and measures $(\mu \mathrm{m})$ of spicules of $T$. variabilis detected in the three studied sections.

\begin{tabular}{lcc}
\hline $\begin{array}{l}\text { Spicule } \\
\text { Categories }\end{array}$ & $\begin{array}{c}\text { Measures } \\
\text { length }\end{array}$ & $\begin{array}{c}\text { Average } \\
\text { width }\end{array}$ \\
\hline $\begin{array}{l}\text { Gemmoscleres } \\
\text { Fig. 4d - scarce }\end{array}$ & 16 & 1.5 \\
Megascleres & 205 & 11.5 \\
\hline
\end{tabular}

Corvoheteromeyenia australis

(Bonetto and Ezcurra de Drago 1966)

Figs. 4e, f, g; Table IV

Corvomeyenia australis Bonetto and Ezcurra de Drago (1966): 137, Lam. III.

Corvoheteromeyenia australis Ezcurra de Drago (1979): 110, Figs. 7-9, 19-22; Tavares et al. (2003): 177, Fig. 16.

TABLE IV

Category and measures $(\mu \mathrm{m})$ of spicules of $C$. australis detected in the three studied sections. The longer slim and spiny birrotulate microscleres of the species present in sediments are quite thin and as such reduced to spiny oxeas.

\begin{tabular}{lccc}
\hline Spicule & Measures & $\begin{array}{c}\text { Average } \\
\text { length }\end{array}$ & $\begin{array}{c}\text { Average } \\
\text { width }\end{array}$ \\
Categories & & & \\
\hline
\end{tabular}

Birrotulate

microscleres - Fig. $4 \mathrm{e}$

Isoquela microscleres

Fig. 4f - scarce

12

0.6

Long gemmoscleres

Fig. $4 \mathrm{~g}$

88

Short gemmoscleres

Fig. $4 \mathrm{~g}$ - scarce

48

Megascleres

510

7.1 


\section{Heterorotula fistula}

Volkmer-Ribeiro and Motta (1995)

Fig. 5a; Table V

Heterorotula fistula Volkmer-Ribeiro and Motta (1995): 151, Figs. 1-23; Volkmer-Ribeiro et al. (1998b): 273; Parolin et al. (2007): 20, Figs. 4C, C1, E, E1; (2008): 191, Fig. 6E; Almeida et al. (2009): 126, Fig. 2F.

\section{TABLE V}

Category and measures $(\mu \mathrm{m})$ of spicules of $\boldsymbol{H}$. fistula detected in the three studied sections. Spicules are scarce, and only the long category of gemmoscleres is seen.

\begin{tabular}{lccc}
\hline $\begin{array}{l}\text { Spicule } \\
\text { Categories }\end{array}$ & Measures & $\begin{array}{c}\text { Average } \\
\text { length }\end{array}$ & $\begin{array}{c}\text { Average } \\
\text { width }\end{array}$ \\
\hline
\end{tabular}

Long gemmoscleres

Fig. $5 \mathrm{a}$ - scarce $\quad 128 \quad 2.8$

Corvospongilla seckti

Bonetto and Ezcurra de Drago (1966)

Fig. 5b; Table VI

Corvospongilla seckti Bonetto and Ezcurra de Drago (1966): 133, Lam. II; (1969): 352; (1970): 52; Batista and Volkmer-Ribeiro (2002): 129; Batista et al. (2003): 530; Tavares et al. (2003): 177, Fig. 14; Batista et al. (2007): 611, Fig. 33; Parolin et al. (2007): 21, Figs. 4A, 5.

Corvospongilla böhmii Volkmer-Ribeiro et al. (1975): 38, Fig. 7; non Corvospongilla böhmii (Hilgendorf 1883), Volkmer-Ribeiro et al. (1981): 16, Figs. 6-9; De Rosa-Barbosa (1984): 130.

TABLE VI

Category and measures $(\mu \mathrm{m})$ of spicules of $C$. seckti detected in the studied sections. Spicules are scarce.

\begin{tabular}{|c|c|c|c|}
\hline $\begin{array}{l}\text { Spicule } \\
\text { Categories }\end{array}$ & Measures & $\begin{array}{l}\text { Average } \\
\text { length }\end{array}$ & $\begin{array}{c}\text { Average } \\
\text { width }\end{array}$ \\
\hline Gemmoscleres & & 45 & 6.2 \\
\hline $\begin{array}{l}\text { Quela } \\
\text { microscleres }\end{array}$ & & 18 & 1.2 \\
\hline $\begin{array}{l}\text { Megascleres } \\
\text { Fig. } 5 b\end{array}$ & & 129 & 11 \\
\hline
\end{tabular}

Eunapius fragilis

(Leidy 1851)

Fig. 5c; Table VII

Spongilla fragilis Leidy (1851): 278.

Eunapius fragilis Penney and Racek (1968): 25, Fig. 1; Volkmer-Ribeiro (1999): 4; Tavares et al. (2003): 172, Fig. 7; Batista and Volkmer-Ribeiro (2002): 129.

TABLE VII

Category and measures $(\mu \mathrm{m})$ of spicules of $E$. fragilis detected in the studied sections. Spicules are scarce.

\begin{tabular}{|c|c|c|c|}
\hline $\begin{array}{l}\text { Spicule } \\
\text { Categories }\end{array}$ & Measures & $\begin{array}{l}\text { Average } \\
\text { length }\end{array}$ & $\begin{array}{c}\text { Average } \\
\text { width }\end{array}$ \\
\hline $\begin{array}{l}\text { Gemmoscleres } \\
\text { Fig. } 5 c\end{array}$ & & 75 & 8 \\
\hline
\end{tabular}

\section{Oncosclera navicella}

(Carter 1881)

Fig. 5d; Table VIII

Spongilla navicella Carter (1881): 87, Figs. 4a-g.

Oncosclera navicella Volkmer-Ribeiro (1970): 437, Fig. 4; Tavares and Volkmer-Ribeiro (1997): 
103, Figs. 11-14, 16; Batista and Volkmer-Ribeiro (2002): 132; Batista et al. (2003): 531; Pinheiro et al. (2003): 3, Figs. 2a, c; Tavares et al. (2003): 177, Fig. 9; Parolin and Volkmer-Ribeiro (2005): 1009, Figs. 23-28; Batista et al. (2007): 623, Fig. 36.

TABLE VIII

Category and measures $(\mu \mathrm{m})$ of spicules of $\boldsymbol{O}$. navicella detected in the studied sections. Spicules are scarce; however, the gemmoscleres are more robust than reported in the original description.

\begin{tabular}{|c|c|c|c|}
\hline $\begin{array}{l}\text { Spicule } \\
\text { Categories }\end{array}$ & Measures & $\begin{array}{c}\text { Average } \\
\text { length }\end{array}$ & $\begin{array}{c}\text { Average } \\
\text { width }\end{array}$ \\
\hline
\end{tabular}

Gemmoscleres

174 18

Fig. 5d

Megascleres scarce

Metania spinata

(Carter 1881)

Fig. 5e; Table IX

Tubella spinata Carter (1881): 96, Figs. 2B, 4D, E; Traxler (1895): 64, Figs. 1-3, 8, 9, 12, 14, 15, 20, 21.

Metania spinata Volkmer-Ribeiro (1984): 544, Figs. 5-7; (1986): 498, Figs. 3A, 5; (1990): 325, Figs. 2a, 3a; (1992): 322, Figs. 2B, 4D, E; VolkmerRibeiro and Costa (1992): 8, Figs. 1E, 4; VolkmerRibeiro and Motta (1995): 149; Volkmer-Ribeiro et al. (1998a): 274, (1998b): 411; Volkmer-Ribeiro (1999): 5; Parolin et al. (2003): 17; Parolin et al. (2008): 191, Figs. 6D, 7C, G; Almeida et al. (2009): 126, Figs. 2C, D.

TABLE IX

Category and measures ( $\mu \mathrm{m})$ of spicules of $M$. spinata detected in the three studied sections.

\begin{tabular}{lccc}
$\begin{array}{l}\text { Spicule } \\
\text { Categories }\end{array}$ & Measures & $\begin{array}{c}\text { Average } \\
\text { length }\end{array}$ & $\begin{array}{c}\text { Average } \\
\text { width }\end{array}$ \\
\hline
\end{tabular}

Gemmoscleres scarce and broken - Fig. 5e

$\begin{array}{lcc}\text { Microscleres - Fig. 5e } & 47 & 1.4 \\ \text { Alpha megascleres } & 280 & 29 \\ \begin{array}{l}\text { Beta megascleres } \\ \text { scarce }\end{array} & 220 & 21\end{array}$

\section{Corvomeyenia thumi}

(Traxler 1895)

Fig. 5f; Table X

Tubella thumi Traxler (1895): 64, Figs. 6, 7, 10, $11,18$.

Metania thumi Penney and Racek (1968): 148.

Corvomeyenia thumi Volkmer-Ribeiro (1992): 320, Figs. 2A, 6, 8A; Martin et al. (1992): 190; Sifeddine et al. (1994): 1647; Volkmer-Ribeiro and Motta (1995): 155; Volkmer-Ribeiro and Turcq (1996): 186, Figs. 1-4; Cordeiro et al. (1997): 815; Turcq et al. (1998): 140; Volkmer-Ribeiro et al. (1998a): 273, (1998b): 410; Volkmer-Ribeiro (1999): 5; Sifeddine et al. (2001): 231; Cordeiro et al. (2008): 51; Almeida et al. (2009): 126.

\section{TABLE X}

Category and measures $(\mu \mathrm{m})$ of spicules of $C$. thumi detected in the studied sections.

\begin{tabular}{lccc}
\hline $\begin{array}{l}\text { Spicule } \\
\text { Categories }\end{array}$ & Measures & $\begin{array}{c}\text { Average } \\
\text { length }\end{array}$ & $\begin{array}{c}\text { Average } \\
\text { width }\end{array}$ \\
\hline
\end{tabular}

Gemmoscleres scarce and broken - Fig. $5 \mathrm{f}$

Microscleres - scarce 3.9 0.2

Megascleres

$490 \quad 12$




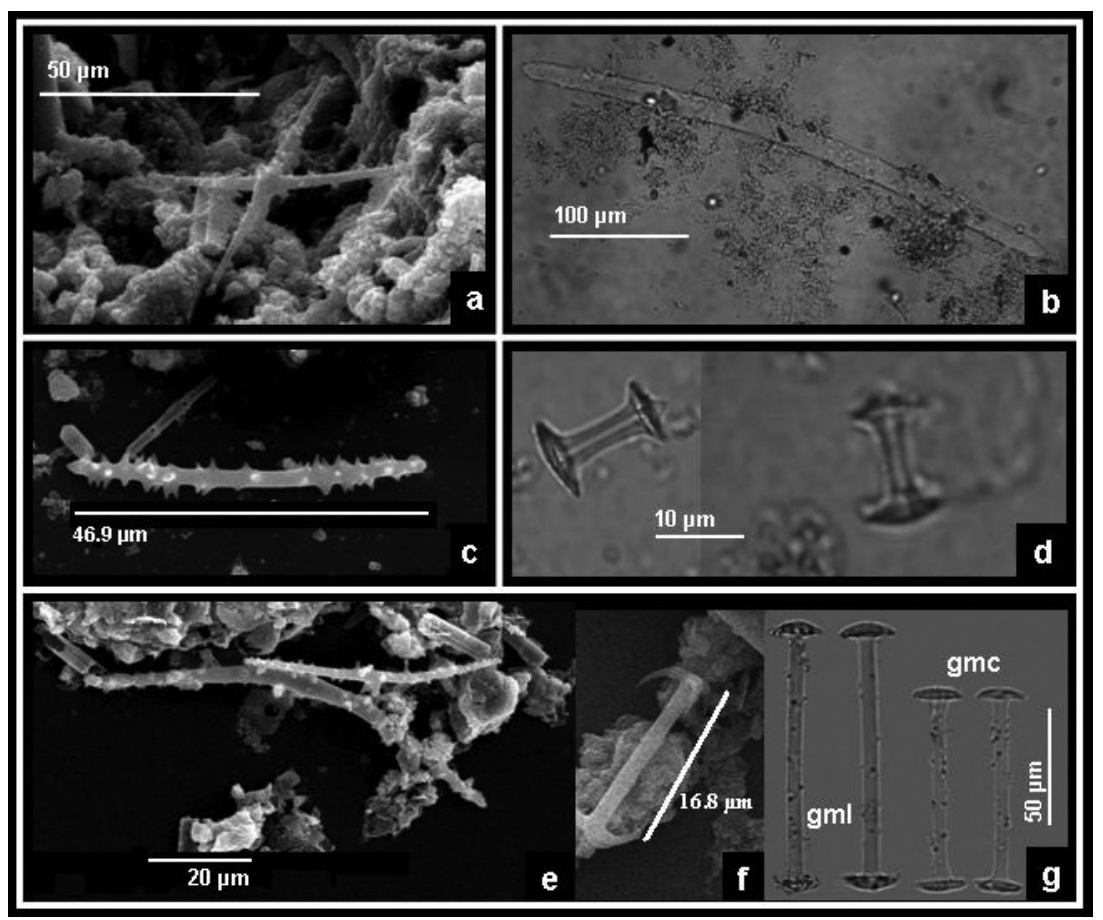

Fig. 4. Scanning Electron Microscope images (a, c, e, f) and Optical Microscope picture (b, d, g) of the sponge spicules found in the rocks of the Cemitério paleolake. a. Dosilia pydanieli Volkmer-Ribeiro (1992): a. microsclere; b, c. Radiospongilla amazonensis Volkmer-Ribeiro and Maciel (1983): b. megasclere, c. gemmosclere; d. Trochospongilla variabilis Bonetto and Ezcurra de Drago (1973): gemmoscleres; e, f, g. Corvoheteromeyenia australis (Bonetto and Ezcurra de Drago 1966): e. spiny oxea microscleres, f. chela microsclere, g. long (gml) and short (gmc) gemmoscleres.

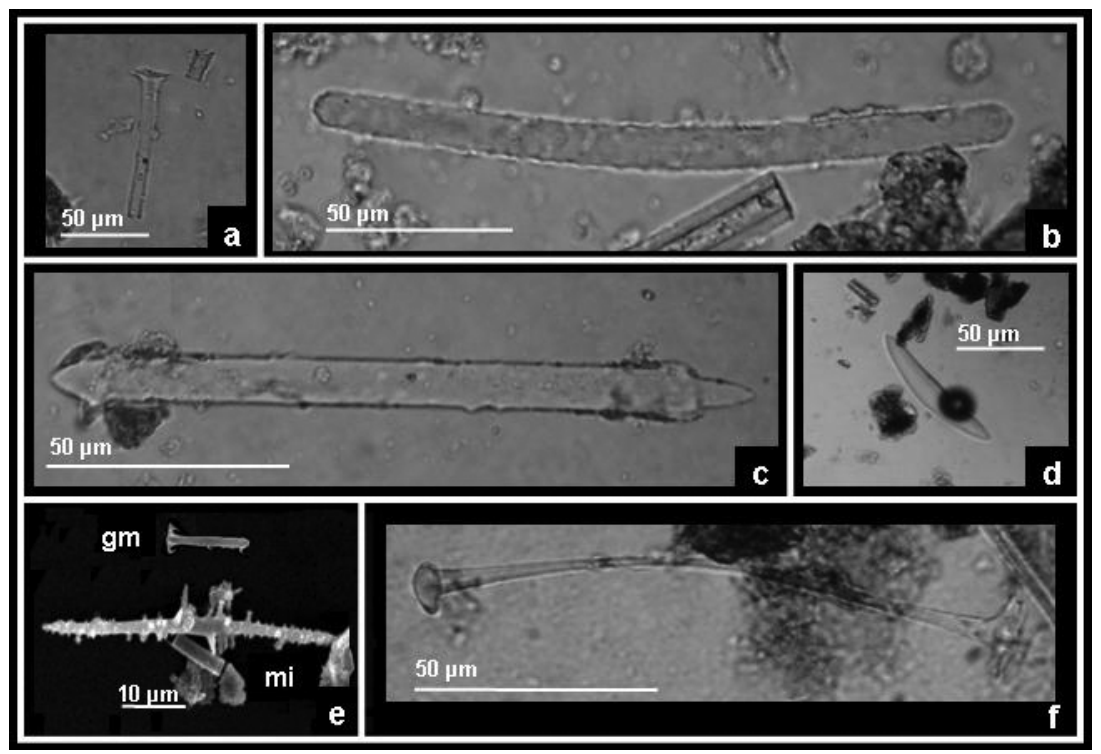

Fig. 5. Scanning Electron Microscope images (, , b, c, f) and Optical Microscope picture (e) of the sponge spicules found in the rocks of the Cemitério paleolake. a. Heterorotula fistula Volkmer-Ribeiro and Motta (1995): fragment of long gemmosclere; b. Corvospongilla seckti Bonetto and Ezcurra de Drago (1966): megasclere; c. Eunapius fragilis (Leidy 1851): gemmosclere; d. Oncosclera navicella (Carter 1881): gemmosclere; e. Metania spinata (Carter 1881): microsclere (mi) and fragment of gemmosclere (gm); f. Corvomeyenia thumi (Traxler 1895): gemosclere. 
SPECIFIC SPONGE COMPOSITION AT THE BIOfACIES

\section{Section 1 (Fig. 6)}

Layer 1: Few spicules of C. seckti, M. spinata, D. pydanieli and C. australis.

Layer 2: Few spicules of $C$. seckti and $O$. navicella.

Layer 3: Spicules absent.

Layer 4: Few spicules of M. spinata, D. pydanieli, C. australis, $R$. amazonensis and T. variabilis.

Layer 5: Spongofacies with spicules of $M$. spinata, D. pydanieli, C. australis, R. amazonensis and $T$. variabilis.

Layer 6: Spongofacies as in Layer 5.

Layer 7: Few spicules, as in Layer 4.

Layer 8: Spicules absent.

Layer 9: Spongofacies as in Layer 5.

Layer 10: Spongofacies as in Layer 5.

Layer 11: Spongofacies as in Layer 5.

Layer 12: Few spicules, as in Layer 4.

Layer 13: Few spicules, as in Layer 4.

Layer 14: Spongofacies as in Layer 5.

Layer 15: Few spicules of M. spinata, D. pydanieli and $C$. australis.

Layer 16: Few spicules, as in Layer 15.

Layer 17: Spicules absent.

Layer 18: Spicules absent.

\section{Section 2 (Fig. 7)}

Layer 1: Few spicules of E. fragilis, M. spinata, D. pydanieli, $R$. amazonensis, T. variabilis, $C$. australis, H. fistula, C. seckti and O. navicella.

Layer 2: Few spicules, differing from that of Layer 1 by the absence of $E$. fragilis and $O$. navicella.

Layer 3: Spongofacies of M. spinata, D. pydanieli, $R$. amazonensis, C. australis, $H$. fistula and C. seckti.

Layer 4: Spongofacies differing from that of Layer 3 by the absence of $C$. seckti.

Layer 5: Few spicules of $C$. seckti.

Layer 6: Few spicules of $H$. fistula.
Layer 7: Few spicules of $H$. fistula and $C$. seckti.

Layer 8: Spicules absent.

Layer 9: Spicules absent.

Layer 10: Spicules absent.

Layer 11: Spongofacies with spicules of $M$. spinata, D. pydanieli, $R$. amazonensis, . variabilis, C. australis, $H$. fistula and C. thumi.

Layer 12: Spongofacies differing from that of Layer 11 by the presence of $O$. navicella.

Layer 13: Spongofacies differing from that of Layer 11 by the absence of $R$. amazonensis and C. thumi.

Layer 14: Spongofacies differing from that of Layer 11 by the absence of $R$. amazonensis, $T$. variabilis and C. thumi.

Layer 15: Spongofacies differing from that of Layer 11 by the absence of $C$. seckti and $O$. navicella.

Layer 16: Spongofacies differing from that of Layer 11 by the absence of $C$. thumi.

\section{Section 3 (Fig. 8)}

Layer 1: Few spicules of D. pydanieli, R. amazonensis, T. variabilis and C. australis.

Layer 2: Spongofacies with spicules of $D$. pydanieli, R. amazonensis, T. variabilis, C. australis, C. thumi and M. spinata.

Layer 3: Spongofacies with spicules of $D$. pydanieli, $R$. amazonensis, T. variabilis, $C$. australis and M. spinata.

Layer 4: Spongofacies as in Layer 3.

Layer 5: Few spicules of D. pydanieli, R. amazonensis, $T$. variabilis, $C$. australis and $M$. spinata.

Layer 6: Spongofacies as in Layer 3.

Layer 7: Spongofacies as in Layer 3.

Layer 8: Spongofacies as in Layer 3.

Layer 9: Spongofacies as in Layer 3.

Layer 10: Spongofacies as in Layer 3.

Layer 11: Spongofacies as in Layer 3.

Layer 12: Spongofacies as in Layer 3.

Layer 13: Spongofacies as in Layer 3. 


\section{STRATIGRAPHIC RANGES}

Spicules of M. spinata, D. pydanieli and C. australis were present throughout Section 1 (from Layer 1 to 16); the ones of $R$. amazonensis and T. variabilis were present from Layer 4 to 16. C. seckti and O. navicella appeared with rare spicules in Layers 1 and 2 (Fig. 6).

Spicules of $D$. pydanieli, $R$. amazonensis, $T$. variabilis, $C$. australis and $H$. fistula were present throughout Section 2 (from Layer 1 to 16); the ones of $C$. seckti and $O$. navicella from Layer 1 to 13, and those of $C$. thumi from Layer 11 to 15. Rare spicules of $E$. fragilis were seen in Layer 1 (Fig. 7).

Spicules of $D$. pydanieli, $R$. amazonensis, $T$. variabilis and $C$. australis were present throughout Section 3 (from Layer 1 to 13), and the ones of $M$. spinata from Layer 2 to 13 . Rare spicules of $C$. thumi were seen in Layer 2 (Fig. 8).

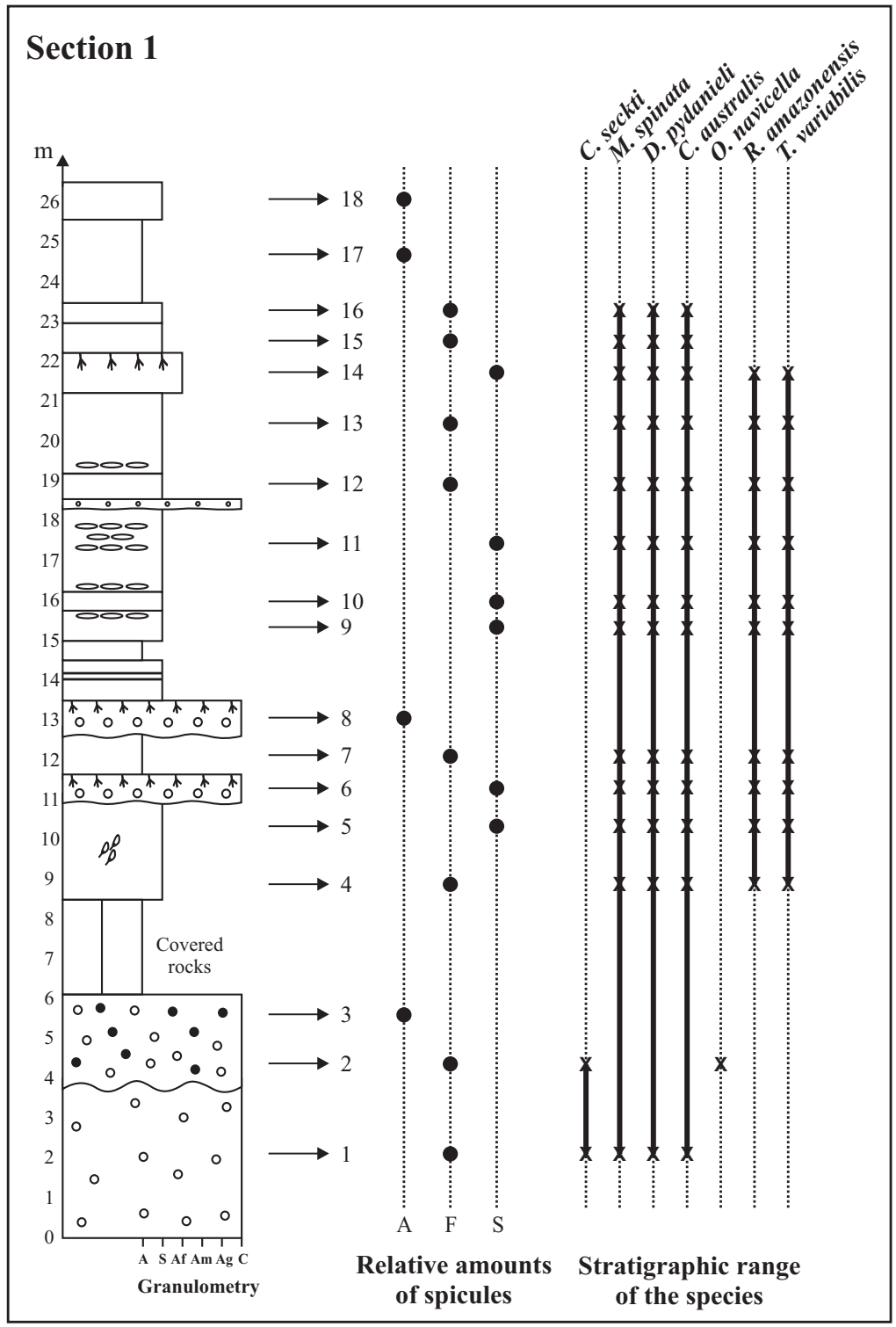

Fig. 6. Profile of Section 1 (meters) vis-a-vis the corresponding relative amounts of sponge spicules (A, absent; F. few; S, spongofacies) and stratigraphic range of the identified species. (X, occurrence of a particular species; A, argillite; S, siltstone; Af, fine sandstone; Am, medium sandstone; Ag, coarse sandstone; C, conglomerate). Legend of rocks as Figure 3. From V.S.M., unpublished data. 


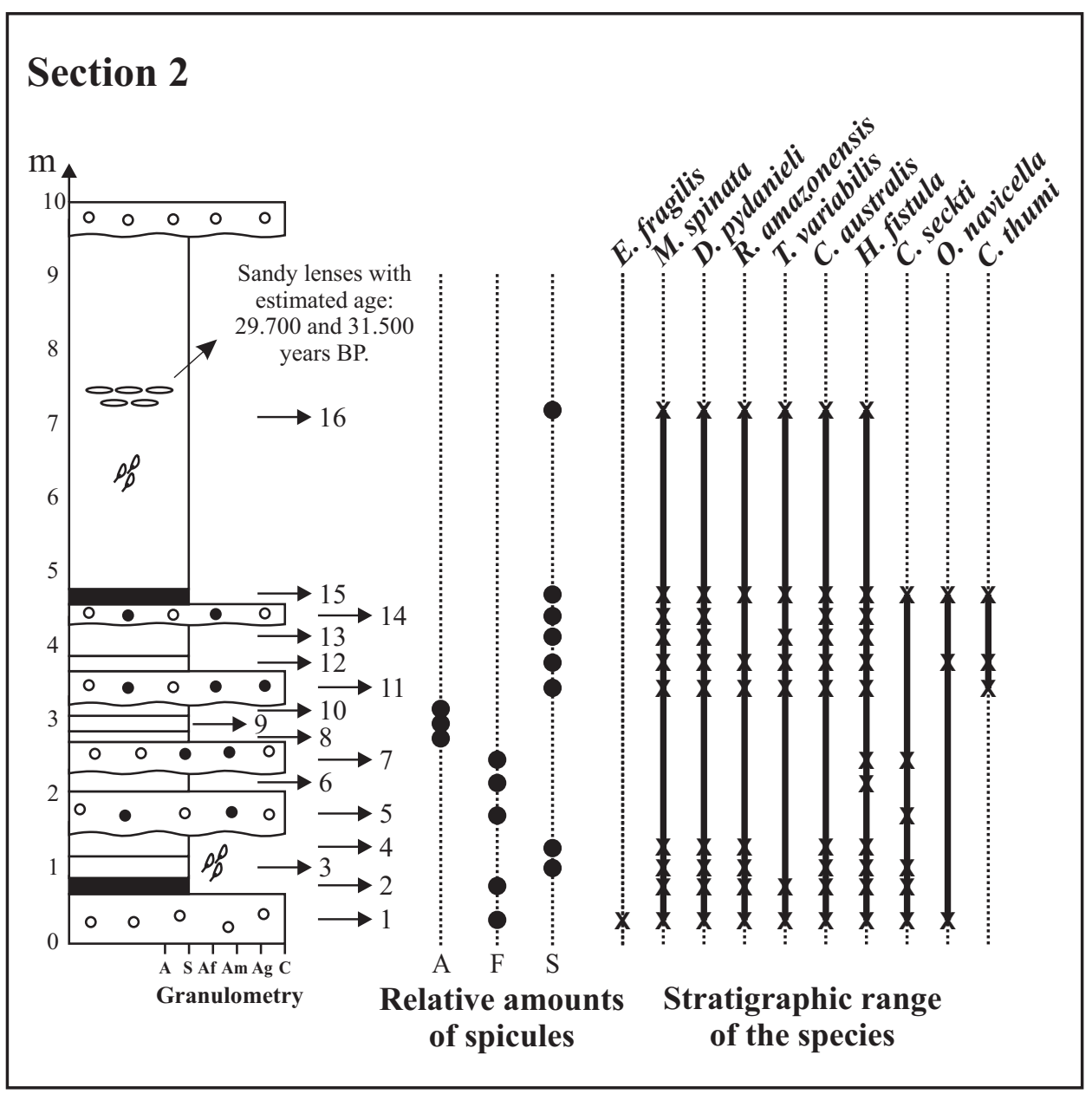

Fig. 7. Profile of Section 2 (meters) vis-a-vis the corresponding relative amounts of sponge spicules (A, absent; F. few; S, spongofacies) and stratigraphic range of the identified species. (X, occurrence of a particular species; A, argillite; S, siltstone; Af, fine sandstone; Am, medium sandstone; Ag, coarse sandstone; C, conglomerate). Legend of rocks as Figure 3. From V.S.M., unpublished data.

\section{DISCUSSION AND CONCLUSION}

The spicules found in the rocks of the Cemitério Paleolake revealed a predominance of sponges typical of lentic paleoenvironments: Metania spinata (Carter 1881), Dosilia pydanieli Volkmer-Ribeiro (1992), Radiospongilla amazonensis VolkmerRibeiro and Maciel (1983), Trochospongilla variabilis Bonetto and Ezcurra de Drago (1973), Corvoheteromeyenia australis (Bonetto and Ezcurra de Drago 1966), Corvomeyenia thumi (Traxler 1895) and Heterorotula fistula VolkmerRibeiro and Motta (1995) (Figs. 4, 5; Tables I,
II, III, IV, V, IX, X). With the exception of the last two, these species are abundant in the rocks and exhibit a prolonged stratigraphic range in the three analyzed sections (Figs. 6, 7, 8). The marked occurrence of this assemblage throughout the stratigraphic columns, comprising 25 layers characterized as spongofacies [Layers 5, 6, 9, 10, 11 and 14 from Section 1 (Fig. 6), Layers 3, 4, 11, 12, 13, 14, 15 and 16 from Section 2 (Fig. 7), and Layers 2, 3, 4, 6, 7, 8, 9, 10, 11, 12 and 13 from Section 3 (Fig. 8)], confirms the lentic nature of the system and indicates the assemblage as indigenous to the Cemitério Paleolake. 


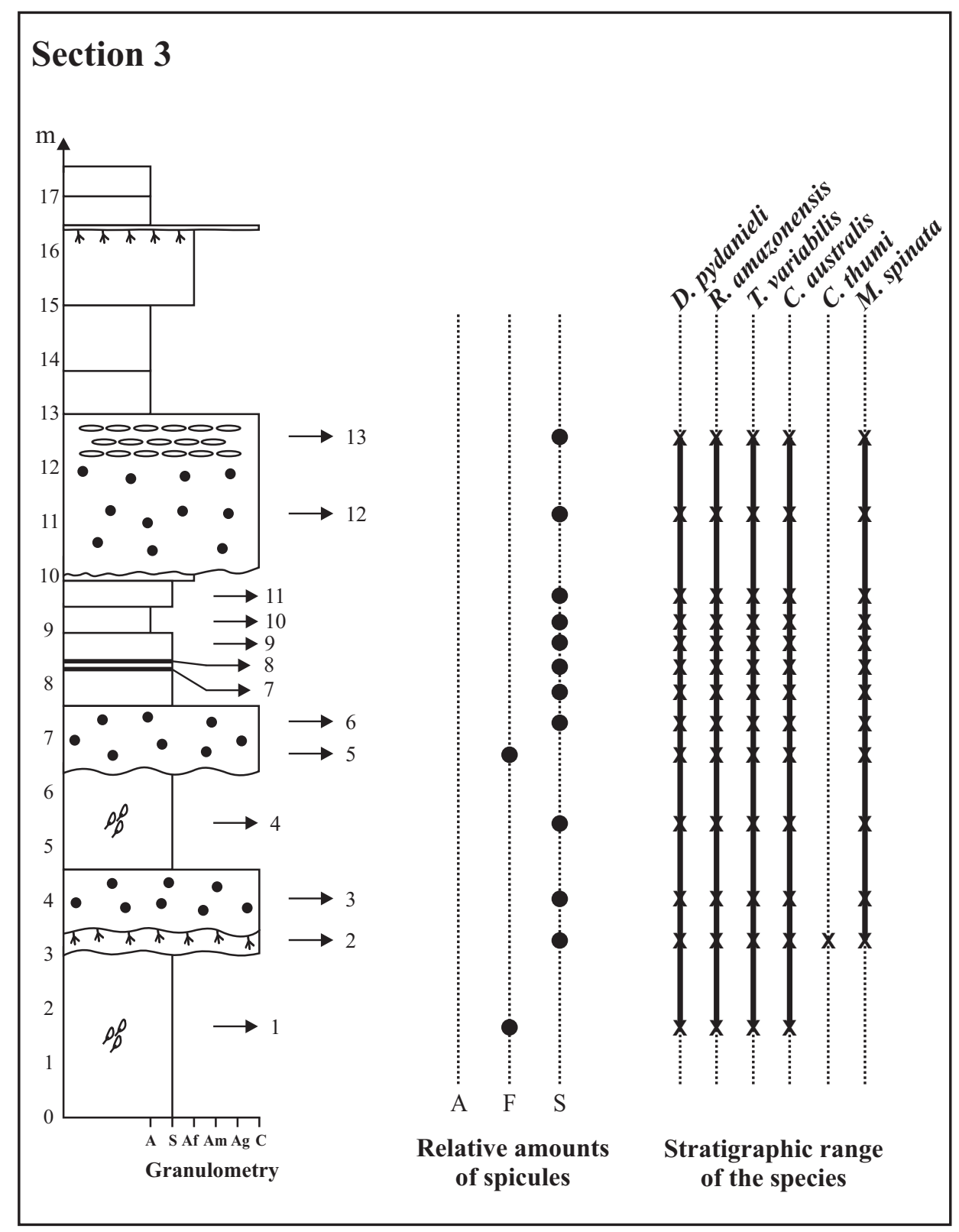

Fig. 8. Profile of Section 3 (meters) vis-a-vis the corresponding relative amounts of sponge spicules (A, absent; F. few; S, spongofacies) and stratigraphic range of the identified species. (X, occurrence of a particular species; A, argillite; S, siltstone; Af, fine sandstone; Am, medium sandstone; Ag, coarse sandstone; C, conglomerate). Legend of rocks as Figure 3. From V.S.M., unpublished data.

Except for the species $C$. australis, the lentic assemblage found in the rocks of the Cemitério paleolake was recorded in spongillite deposits in the Cerrado region of Conceição das Alagoas and Santa Vitória, Minas Gerais State; São Simão, Goiás State; Paranaiba, Mato Grosso do Sul State, and Porto Ferreira, São Paulo State (VolkmerRibeiro and Motta 1995, Volkmer-Ribeiro 1992, Almeida et al. 2009). The species H. fistula has also been described from spongillite deposits found in the region of Conceição das Alagoas, Minas Gerais State (Volkmer-Ribeiro and Motta op cit.), and was 
subsequently registered in a column of sediment recovered from the floodplain of the Esperança River, Taquarussu region, Mato Grosso do Sul State (Parolin et al. 2007). Intriguingly, no living specimens of $H$. fistula have ever been recorded and, as a consequence, their ecology and habitat preferences are generally unknown. However, Volkmer-Ribeiro and Motta (1995) pointed out that the species of the genus Heterorotula, hitherto endemic to Australia, appear in environments that are seasonally exposed to drought and form delicate crusts on the roots of aquatic vegetation, with a consistency ranging from fragile to hard, but brittle. Volkmer-Ribeiro (1992) also reported this same assemblage, with the exception of $H$. fistula, in a seasonal lake on the island of Maraca, Roraima State, and in lakes between Boa Vista and the island of Maraca. This island is considered to exhibit a transitional environment between Amazon Forest and the Cerrado. The temporary lake consists of a small body of water that during the rainy season does not exceed two meters in the center and can dry up completely at the height of the dry season. Volkmer-Ribeiro et al. (1998b) noticed the similarity of this assemblage of live sponges, occurring in the Brazilian Cerrado Biome, with the assemblage found in the spongillite, and pointed to the possibility that these deposits represent a remnant of typical lakes from the Cerrado. Later, Volkmer-Ribeiro (1999) reported the occurrence of the species R. amazonensis, D. pydanieli, $T$. variabilis, M. spinata and C. thumi for the state of São Paulo, and indicated that assemblage as typical of lakes in the current Cerrado Biome.

C. australis, identified for the first time in an assemblage formed by biosiliceous deposits, is endemic to South America and was described based on the material collected in Argentina, with the type locality being Setúbal Lake, but also in Don Felipe Lake and in waterbodies of Carabajal Island, being all of them environments of the Middle Paraná River floodplain that is located in the province of
Santa Fe, Argentina (Ezcurra de Drago 1979). The specimens were found near the mouths of streams, exposed to considerable flowing water (Ezcurra de Drago op cit.). Regarding Brazil, the species was first recorded for the Jacuí Delta, Rio Grande do Sul, encrusting the roots of the macrophyte Eichornia azurea (Sw.) Kunth (Tavares et al. 2003), with very similar environmental characteristics to those of the type locality.

The taxonomic analysis of the basal portion of the Cemitério Paleolake deposit (Layers 1 and 2 from Section 1 and throughout Section 2) (Figs. $6,7)$ also revealed the presence of spicules from the sponges Corvospongilla seckti Bonetto and Ezcurra de Drago (1966), Oncosclera navicella (Carter 1881) and Eunapius fragilis (Leidy 1851) (Fig. 5; Tables VI, VII, VIII), which are indicator species of lotic environments (Batista and Volkmer-Ribeiro 2002, Tavares et al. 2003). The presence of spicules from these three species in the basal rocks, combined with the short stratigraphic range observed, points to the influence of a lotic environment in the proximity of the paleolake, which would be responsible for the transmission of spicules to the depocenter of the basin and results in the deposition and sedimentation of distinct sponge assemblages (sponge species/assemblages characteristic of lentic and lotic environments). It follows that $C$. seckti, O. navicella and E. fragilis constitute elements of the allochthonous sponge fauna from the Cemitério Paleolake. This interpretation is supported by the stratigraphy at Section 1 whose the basal section is dominated by coarse particle sizes suggesting deposition in a strong uni-directional flow.

Parolin et al. (2007) had previously identified the occurrence of continental sponge species that are characteristic of different environments, lotic (Trochospongilla repens Hinde 1888 and $C$. seckti) and lentic ( $R$. amazonensis and H. fistula), in two sediment profiles in the floodplain of the Esperança River, Taquarussu region, Mato Grosso 
do Sul State, Brazil. According to these authors, the species $H$. fistula, which is indicative of lentic environments, occurred from the most basal portion to the top of the deposit, while others occurred only in some layers. Thus, they concluded that there had been a lentic habitat marginal to the river caused by pulses of flooding of the river, which were well defined by the punctuated presence of spicules of $C$. seckti and T. repens. Furthermore, they highlighted the moment when the gemmoscleres of $H$. fistula occurred together with well-formed megascleres of $R$. amazonensis, a species identified as an indicator of peat, showing an increase in the residence of water in the lentic body that was responsible for the accumulation and formation of peat along the banks of the Esperança River from the early Holocene.

The analysis of the basal rocks from the Cemitério Paleolake also allows a discussion regarding their formation. Layers 1, 2, 3 and 4 of Section 2 (Fig. 7) are characterized by the progression of a few spicules (Layer 1,2) to the spongofacies (Layers 3, 4 - Fig 7), indicating that the initial volume of water in the basin was minimum, followed by an increase in water with the probable establishment of macrophytic vegetation, which acts as a substrate for sponges and is always present in shallow lakes. The following layers (Layers 5, 6,7 , Fig 7) show a reduction in spicules, showing a decline in the water column of the basin with the possible occurrence of acid water, which can form karstic lakes in terrains made up of carbonatite rocks. Ribeiro et al. (2001) suggested two hypotheses for the genesis of a "Dry Paleolake", which is a deposit located in the same Catalão complex and is similar to the Cemitério Paleolake. The first one is based on the leaching of the underlying carbonatite and phoscorite, a process that could result in large caves or dolines, thereby decreasing the size of the rock by up to five times. The second hypothesis involves a small-scale localized collapse, which could result in a reduction in the volume of the rock that causes subsidence. Either way, both hypotheses point to the lakes appearing as a result of the erosion occurred in an area of karstic relief. The accumulation of humic substances, which resulted from a natural process of eutrophication caused by the production of macrophyte vegetation in the basin, would contribute to the accelaration of an erosive karstic process that leads to subsidence at the bottom of lakes. The alternation of clay (Layers 2, 3, 4, 6, 8, 9, 10, 12, 13, 15 and 16, Section 2) and conglomerates (Layers 1, 5, 7, 11 and 14, Section 2) is indicative of such a process (Fig. 7).

In addition, we interpret a strong lotic influence at the beginning of the paleolake's history, as indicated by the species C.seckti, O. navicella and E. fragilis (Fig. 6, 7). The conditions of lotic environments may have contributed to greater volumes of water and, consequently, to increased physical and chemical weathering at the bottom of the lake, which is typical of karstic lakes. Auler et al. (2005) report that, at the bottom of these karstic lakes, sediments of allochthonous and autochthonous origin can be found, respectively, derived from the production within the lake system and from the influx of rainwater from the slopes of the drainage basin.

The ages obtained by N.C., unpublished data, for layer 16 of Section 2 (Figs. 3, 7) of the Cemiterio Paleolake allow one aspect to be addressed by this study. The author used two methods of dating for the sediments (sand lenses) found in this layer, thermoluminescence (TL) and optically stimulated luminescence (OSL) (Aitken 1985, Madsen and Murray 2009). TL resulted in an age of $34,700+1$ - 5,000 years BP., while that obtained with OSL was $27,500+/-4,000$ years BP. Considering the range of overlap of the error bars of these two geochronologies, this layer is believed to have an age between 29,700 and 31,500 years BP. (Figs. 3, 7). Given the presence of spongofacies at the base of Section 2, which represents the oldest rocks of the Cemitério Paleolake, with a marked occurrence of the sponge assemblages that are characteristic of lentic environments (M. spinata, D. pydanieli, $R$. 
amazonensis, T. variabilis, H. fistula and C. thumi), it seems reasonable to suggest a maximum age of at least 39,700 years BP., considering the margin of error of the oldest dating.

\section{ACKNOWLEDGMENTS}

The senior author is grateful to Coordenação de Aperfeiçoamento de Pessoal de Nível Superior (CAPES) and the Conselho Nacional de Desenvolvimento Científico e Tecnológico (CNPq), respectively, for the master's scholarship and present doctoral scholarship, which were essential for the development of this research. The co-authors are fellows in productivity of $\mathrm{CNPq}$ (CVR PQ306266/2006-7 and RI PQ309322/20073 , respectively). The authors acknowledge the Fosfértil Mining Company for the permission to material collection and logistic support during the field work. Last, but not least, the authors aknowledge the valuable suggestions offered by two anonymous referees.

\section{RESUMO}

O Paleolago Cemitério, Catalão, Goiás, é um depósito lacustre rico em espículas de esponjas continentais. Essas espículas, que estão presentes em três seções (1-3), foram analisadas para identificação taxonômica das espécies, a fim de reconstruir o paleoambiente do Quaternário tardio. Foi encontrada uma assembleia nativa de esponjas lênticas, consistindo de Metania spinata (Carter 1881), Dosilia pydanieli Volkmer-Ribeiro (1992), Radiospongilla amazonensis Volkmer-Ribeiro e Maciel (1983), Trochospongilla variabilis Bonetto e Ezcurra de Drago (1973), Corvomeyenia thumi (Traxler 1895), Heterorotula fistula Volkmer-Ribeiro e Motta (1995), acrescida de Corvoheteromeyenia australis (Bonetto e Ezcurra de Drago 1966), que aqui tem o seu primeiro registro em assembleia formadora de depósitos biosilicosos. Além disso, na base das seções, foram detectadas espículas de esponjas de ambiente lótico, incluindo Corvospongilla seckti Bonetto e Ezcurra de Drago (1966), Oncosclera navicella (Carter 1881) e Eunapius fragilis (Leidy 1851), o que sugere uma contribuição de águas com fluxo. Foram identificados 25 horizontes de espongofácies produzidos por assembleia de esponjas típicas de ambiente lêntico, datado de pelo menos 39.700 anos AP., e atualmente ocorrente em lagoas típicas do Bioma Cerrado.

Palavras-chave: Bioma Cerrado, esponjas continentais, paleointerpretações do Quaternário, sedimentos, espículas.

\section{REFERENCES}

AITKEN MJ. 1985. Thermoluminescence Dating. London: Academic Press, 359 p.

ALMEIDAACS, VOLKMER-RIBEIROC, VARAJÃO AFDC, GOMES NS AND VARAJÃO CACV. 2009. Espículas de esponjas continentais nos sedimentos Cenozóicos do noroeste de Minas Gerais, como indicadores paleoambientais. Rev Bras Paleontol 12(2): 123-138.

Auler SA, PILÓ LB AND SAADI A. 2005. Ambientes Cársticos. In: SOUZA CRG ET AL. (Eds), Quaternário do Brasil, Ribeirão Preto: Holos, Ribeirão Preto, Brasil, p. 321-337.

BATISTA TCA AND VOLKMER-RIBEIRO C. 2002. Comunidades de esponjas do curso superior dos rios Paraná (Goiás) e Paraguai (Mato Grosso), Brasil, com redescrição de Oncosclera schubarti Bonetto and Ezcurra de Drago. Rev Bras Zool 19(1): 123-136.

BATISTA TCA, VolKMER-Ribeiro C, DARWich C AND Alves LF. 2003. Freshwater sponges as indicators of floodplain lake environments and of river rocky bottom in Central Amazonia. Amazoniana 18: 525-549.

BAtista TCA, VolKMER-Ribeiro C AND MelÃo MG. 2007. Espongofauna da Área de Proteção Ambiental Meandros do rio Araguaia (GO, MT, TO), Brasil, com descrição de Heteromeyenia cristalina sp. nov. (Porífera, Demospongiae). Rev Bras Zool 24(3): 608-630.

Bonetto AA AND Ezcurra de Drago I. 1966. Nuevos aportes al conocimiento de las esponjas argentinas. Physis 26(71): 129-140.

Bonetto AA ANd Ezcurra de Drago I. 1969. Notas sistemáticas sobre el género Uruguaya Carter (Porifera, Spongillidae). Physis 28(77): 351-377.

BonetTo AA AND EzCURRA DE Drago I. 1970. Esponjas de los afluentes del Alto Paraná en la Provincia de Misiones. Acta Zool Lilloana 27: 37-58.

BONETTO AA AND EZCURRA DE DRAGO I. 1973. Las esponjas del género Trochospongilla Vejdovsky en aguas argentinas. Physis 32(84): 13-18.

CÂNDIDO JL, VOLKMER-RIBEIRO C AND FÜRSTENAU-OLIVEIRA K. 2010. Dosilia (Porifera, Demospongiae) redefined. Iheringia, Ser Zool 100(4): 425-448. 
CÂNdido JL, VOLKMER-RiBEIRO C, SiMÕES FILHO FL, TURCQ BJ AND Chauvel A. 2000. Microsclere variations of Dosilia pydanieli (Porifera, Spongillidae) in Caracaranã lake (Roraima - Brazil). Palaeoenvironmental implication. Biociências 8(2): 77-92.

CARdoso N And IAnNuzZi R. 2006. Pteridium catalensis sp. nov., uma nova Pteridófita fóssil do Complexo Carbonatítico Catalão I, Goiás. Rev Bras Paleontol 9(3): 303-310.

CARTER HJ. 1881. History and classification of the know species of Spongilla. Ann Mag Nat Hist 5(7): 77-107.

Cordeiro RC, Turcq B, Suguio K, Silva AO, Sifeddine A AND VolKMER-RIBEIRO C. 2008. Holocene fires in East Amazonia (Carajás), new evidences, chronology and relation with paleoclimate. Global Planet Change 61(1-2): 49-62.

Cordeiro RC, TurcQ B, Suguio K, VolKMER-Ribeiro C, Silva AO, Sifeddine A AND MARTIN L. 1997. Holocene environmental changes in Carajás Region (Pará, Brazil) recorded by lacustrine deposits. Verh Internat Verein Limnol 26: 814-817.

De Rosa-Barbosa R. 1984. Reavaliação da fauna espongológica continental do Estado do Rio Grande do Sul, Brasil, frente a novas coletas. Iheringia, Ser Zool 64: 127-148.

EZCURRA DE DRAGO I. 1979. Um nuevo gênero sudamericano de esponjas: Corvoheteromeyenia gen. nov. (Porífera Spongillidae). Neotropica 25(74): 109-118.

Gaiser EE, Brooks MJ, KenNey WF, Schelske CL AND TAYLOR BE. 2004. Interpreting the Hydrological history of temporary ponds from chemical and microscopic characterization of siliceous microfossils. J Paleolimnol 1: 63-76.

HALl BV AND HerRmann SJ. 1980. Paleolimnology of three species of freshwater sponges (Porifera: Spongillidae) from a sediment core of a Colorado semidrainage mountain lake. Trans Am Microsc Soc 99(1): 93-100.

HARRISON FW. 1988. Utilization of freshwater sponges in paleolimnological studies. Palaeogeogr Palaeoclimatol Palaeoecol 62: 387-397.

Harrison FW, Gleason PJ AND Stone PA. 1979. Paleolimnology of Lake Okeechobee, Florida: an analysis utilizing spicular components of freshwater sponges (Porifera: Spongillidae). Notul Nat Acad Nat Sci Philadelphia 454: 1-6.

HARRISON FW AND WARNER BG. 1986. Fossil freshwater sponges (Porifera: Spongillidae) from Western Canada: An Overlooked Group of Quaternary Paleoecological Indicators. Trans Am Microsc Soc 105(2): 110-120.

LEIDY J. 1851. Spongilla fragilis. Proc Acad Nat Sci Phila 5: 278.

MADSEN AT AND MURRAY AS. 2009. Optically stimulated luminescence dating of young sediments. Geomorphology 109: 3-16.
Martin L, Absy ML, Fournier M, Mouguiart P, Sifeddine A AND VOLKMER-RIBEIRo C. 1992. Some climatic alterations recorded in South America during the last 7000 years may be expounded by long-term el niño like conditions. In: ORTLIEB L AND MACHARÉ J (Eds), Paleo-ENSO Records, Lima: OSRTOM-CONCYTEC, Lima, Peru, p. 187-192.

PAROLIN M AND VOLKMER-RIBEIRO C. 2005. Segundo registro de Sterrastrolepis brasiliensis Volkmer-Ribeiro \& De Rosa-Barbosa (Demospongiae, Potamolepidae) com descrição do habitat e de assembléia, Bacia do Rio Paraná, Brasil. Rev Bras Zool 22(4): 1003-1013.

Parolin M, Volkmer-Ribeiro C And Stevaux JC. 2003. Caracterização paleoambiental a partir de espículas silicosas de esponjas em sedimentos lagunares na região de Taquaruçu - MS. In: PALEO 2003, Paleontologia em Destaque 44. Resumos ..., Porto Alegre: Sociedade Brasileira de Paleontologia, p. 17-18.

Parolin M, Volkmer-Ribeiro C ANd SteVaux JC. 2007. Sponge spicules in peaty sediments as paleoenvironmental indicators of the Holocene in the upper Paraná River, Brazil. Rev Bras Paleontol 10(1): 17-26.

Parolin M, Volkmer-Ribeiro C And Stevaux JC. 2008. Use of Spongofacies as a proxy for river-lake paleohydrology in Quaternary deposits of central-western Brazil. Rev Bras Paleontol 11(3): 187-198.

PENNEY JT AND RACEK AA. 1968. Comprehensive revision of a worldwide collection of freshwater sponges (Porifera: Spongillidae). Bull US Nat Mus 272: 184.

PinheIro US, HaJdu E AND CABALlero ME. 2003. Três novos registros de esponjas (Porifera, Demospongiae) para águas continentais do Estado de São Paulo. Bol Mus Nac Zool 498: 1-14.

RACEK AA. 1974. The waters of Merom: A Study of Lake Huleh. IV. Spicular remains of fresh-water sponges (Porifera). Arch Hydrobiol 74: 137-158.

Ribeiro CC, Brod JA, Junqueira-Abrod TC, Gaspar JC AND PETRINOVIC IA. 2001. Pipes de brecha e atividade magmática explosiva no Complexo Alcalino-carbonatítico de Catalão I, Goiás. Rev Bras Geocienc 31(4): 417-426.

Sifeddine A, Frohlich F, Fournier M, Martin L, SERVAnt M, Soubiès F, Turce B, Suguio K And VolkmerRIBEIRO C. 1994. La sedimentation lacustre indicateur de changements des paleoenvironments aucours des 300.000 derniere annees Carajás Amazonie, Brésil. CR Acad Sci Paris 318(2): 1645-1652.

Sifeddine A, Martin L, TurcQ B, Volkmer-Ribeiro C, Soubiès F, Cordeiro RC AND Suguio K. 2001. Variations of the Amazonian rainforest environment: a sedimentological record covering 30,000 years. Palaeogeogr Palaeoclimatol Palaeoecol 168: 221-235.

TAVARES MCM AND VOLKMER-RIBEIRO C. 1997. Redescrição das esponjas de água doce Oncosclera navicella (Carter, 1881) (Potamolepidae) e Spongilla spoliata VolkmerRibeiro \& Maciel, 1983 (Spongillidae). Biociências 5(1): 97-111. 
TAVARES MCM, VOLKMER-Ribeiro C AND DE ROSABARBosA R. 2003. Primeiro registro de Corvoheteromeyenia australis (Bonetto \& Ezcurra de Drago) para o Brasil com chave taxonômica para os poríferos do Parque Estadual Delta do Jacuí, Rio Grande do Sul, Brasil. Rev Bras Zool 20(2): 169-182.

TRAXLER L. 1895. Spikule von Süsswasserschwämmen aus Brasilien. Földt Közl 25: 62-64.

TurcQ B, Sifeddine A, MARTin L, Absy ML, Soubiès F, Suguio K AND VolKMER-Ribeiro C. 1998. Amazon Forest fires: a lacustrine report of 7.000 years. Ambio 27(2): 139-142.

VOLKMER-RIBEIRO C. 1970. Oncosclera-a new genus of freshwater sponges (Porífera - Spongillidae) with redescription of two species. Amazoniana 2(4): 435-442.

VOLKMER-RIBEIRO C. 1981. Porifera. In: HURLBERT SH ET AL. (Eds), Aquatic Biota of Tropical South America, San Diego: San Diego State University, USA, p. 86-95.

VOLKMER-RIBEIRO C. 1984. Evolutionary study of the genus Metania GRAY, 1867 (Porifera: Spongillidae): II. Redescription of two Neotropical species. Amazoniana 7(4): 541-553.

VOLKMER-RIBEIRO C. 1985. Manual de técnicas para a preparação de coleções zoológicas. Sociedade Brasileira de Zoologia, n. 3. São Paulo: CNPq, 6 p.

VOLKMER-RIBEIRO C. 1986. Evolutionary study of the freshwater genus Metania GRAY, 1867: III. Metaniidae, new family. Amazoniana 9(4): 493-509.

VOLKMER-RIBEIRO C. 1990. A new insight into the systematics, evolution and taxonomy of freshwater sponges. In: RÜTZLER K (Ed), New perspectives in Sponge Biology, Washington: Smithsonian Institution Press, Washington, USA, p. 323-331.

VOLKMER-RIBEIRO C. 1992. The freshwater sponges in some peat-bog ponds in Brazil. Amazoniana 12(2): 317-335.

VOLKMER-RIBEIRO C. 1999. Esponjas. In: ISMAEL D ET AL. (Eds), Biodiversidade do Estado de São Paulo, São Paulo: síntese do conhecimento ao final do século XX, 4: Invertebrados de água doce, São Paulo: FAPESP 4, São Paulo, Brasil, p. 1-19.

VOLKMER-RiBeIro C AND COSTA PRC. 1992. On Metania spinata (Carter, 1881) and Metania kiliani n.sp.: Porifera, Metaniidae Volkmer-Ribeiro, 1986. Amazoniana 12(1): 7-16.

VOLKMER-RIBEIRO C, DE ROSA-BARBOSA R AND MANSUR MCD. 1981. Fauna espongológica e malacológica bêntica da Lagoa Negra, Parque Estadual de Itapuã, Rio Grande do Sul. Iheringia, Ser Zool 59: 13-24.
VOLKMER-RIBEIRO C, EZCURRA DE DRAGO I AND PAROLIN M. 2007. Spicules of the freshwater sponge Ephydatia facunda indicate lagoonal paleoenvironment at the pampas of Buenos Aires Province, Argentina. J Coastal Res 50: 449-452.

VolKMer-Ribeiro C, Grosser KM, De Rosa-BARbosa R AND PAULS SM. 1975. Primeiro relato da ocorrência de Espongilideos (Porifera) na bacia do Guaíba, Estado do Rio Grande do Sul. Iheringia, Ser Zool 46: 33-49.

VOLKMER-RIBEIRO C AND MACHADO VS. 2007. Freshwater sponges (Porífera: Demospongiae), indicators of some typical coastal habitats at South America: redescriptions and key to identification. Iheringia, Ser Zool 97(2): 157-167.

VOLKMER-RIBEIRO C AND MACHADO VS. 2009. Freshwater sponges (Porifera, Demospongiae) in a benthic filter feeding community at the Guanacaste Dry Forest, Costa Rica. Iheringia, Ser Zool 99(4): 335-344.

VOLKMER-Ribeiro C AND MACIEL SB. 1983. New freshwater sponges from Amazonian waters. Amazoniana 8(2): 255-264.

VOLKMER-RIBEIRO C, MANSUR MCD, MERA PAS AND RosS SM. 1998b. Biological indicatores in the Aquatic Habitats of the Ilha de Maracá. In: MILLIKEN ET AL. (Eds), MARACÁ: the biodiversity and environment of an Amazonian rainforest, Chichester: J Wiley \& Sons Ltda., Chichester, England, p. 403-414.

VolKMER-Ribeiro C, MARQUes DM, DE Rosa-BARBosa R AND MACHADO VS. 2004. Sponge spicules in sediments indicate evolution of coastal freshwater bodies. J Coastal Res 39: 469-472.

VOLKMER-RIBEIRO C AND MOTTA JFM. 1995. Esponjas formadoras de espongilitos em lagoas no Triângulo Mineiro e adjacências, com indicação de preservação de habitat. Biociências 3(2): 145-169.

VOLKMER-Ribeiro C, MOtTA JFM AND CALLEGARO VLM. 1998a. Taxonomy and Distribution of Brazilian Spongillites. In: WANABE Y AND FUSETANI N (Eds), Sponge Sciences, Tokyo: Springer-Verlag, Tokyo, Japan, p. 271-278.

VOLKMER-RibeIRo C AND PAULS SM. 2000. Esponjas de água dulce (Porífera: Demospongiae) de Venezuela. Acta Biol Venez 20(1): 1-28.

VOLKMER-RIBEIRO C AND TURCQ B. 1996. SEM analysis of silicious spicules of a freshwater sponge indicate paleoenvironmental changes. Acta Microsc 5(B): 186-187. 